\title{
HUBUNGAN FREKUENSI KONSUMSI MAKANAN CEPAT SAJI DENGAN TEKANAN DARAH PADA REMAJA SMP PERMAI PENJARINGAN JAKARTA UTARA
}

\section{CORRELATION BETWEEN FAST FOOD CONSUMPTION FREQUENCY AMONG TEENAGERS IN PERMAI JUNIOR HIGH SCHOOL PENJARINGAN NORTH JAKARTA}

\author{
Heidy $^{*}{ }^{1}$, Sebastian Darvan. ${ }^{1}$ \\ ${ }^{1}$ Departemen Fisiologi, Fakultas Kedokteran, Universitas Katolik Atma \\ Jaya Jl. Pluit Raya No. 2. Penjaringan, 14440
}

\begin{abstract}
ABSTRAK
Hipertensi merupakan sebuah penyakit pada orang dewasa maupun anak-anak dan remaja dengan tingkat mortalitas dan morbiditas yang tinggi. Faktor penyebab hipertensi yang dapat dimodifikasi adalah pola makan dan gaya hidup. Pola makan sering mengonsumsi western fast food yang tinggi energi, lemak jenuh, garam, dan rendah serat dapat meningkatkan risiko hipertensi. Penelitian ini bertujuan untuk mengetahui apakah terdapat hubungan antara frekuensi konsumsi makanan cepat saji dengan tekanan darah pada remaja kelas IX SMP Permai Penjaringan Jakarta Utara dengan menggunakan metode penelitian analitik potong lintang. Dari 123 responden didapatkan 40 responden jarang mengonsumsi makanan cepat saji yang terbagi dari 35 responden dengan tekanan darah normal dan 5 responden dengan tekanan darah meningkat. Dari 83 responden yang sering mengonsumsi makanan cepat saji terdapat 72 responden dengan tekanan darah normal dan 11 responden dengan tekanan darah meningkat. Tidak terdapat hubungan antara frekuensi konsumsi makanan cepat saji dengan tekanan darah pada remaja SMP Permai Penjaringan Jakarta Utara.
\end{abstract}

Kata kunci: makanan cepat saji, remaja, tekanan darah 


\begin{abstract}
Hypertension is a disease in adults as well as children and adolescents with high mortality and morbidity. Causes of hypertension that can be modified include diet and lifestyle. Diet that often consume western fast food that is high in energy, saturated fat, salt, and low fiber can increase the risk of hypertension. This research aimed to know whether there was a correlation between fast food consumption frequency with blood pressure among teenagers of class IX in Permai Junior Highschool, used a cross sectional analytic study. Out of 123 respondents, we obtained 40 respondents that did not consume fast food often, there were 35 respondents with normal blood pressure and 5 respondents with elevated blood pressure. Of the 83 respondents that consume fast food often, there were 72 respondents with normal blood pressure and 11 respondents with elevated blood pressure. There was no correlation between fast food consumption frequency with blood pressure among teenagers in Permai Junior Highschool.
\end{abstract}

Keywords: blood pressure, fast food, teenagers

\title{
Penulis korespondensi:
}

Heidy

Departemen Fisiologi, Universitas Katolik Atma Jaya

J1. Pluit Raya No. 2, Penjaringan. 14440

haihei_dee@yahoo.com

\section{PENDAHULUAN}

Hipertensi adalah peningkatan tekanan darah diatas normal, penyakit ini dapat terjadi pada orang dewasa maupun anak-anak dan remaja dengan tingkat mortalitas dan morbiditas yang tinggi. Hipertensi merupakan faktor utama terjadinya penyakit sistem jantung dan pembuluh darah pada negara-negara berkembang, salah satunya Indonesia dimana sekitar 33 juta orang dari seluruh penduduk Indonesia berusia di atas 40 tahun menderita hipertensi. Penderita hipertensi yang tidak terkontrol memiliki risiko yang lebih besar untuk terjadinya gangguan pada pembuluh darah di masa yang akan datang. (Hussain MA. et al, 2016)

Menurut American Heart Association 2017, sebanyak $45.6 \%$ penduduk dewasa di Amerika Serikat menderita hipertensi dan terjadi 78.862 kematian yang disebabkan oleh hipertensi. Jumlah penderita hipertensi meningkat sebesar 10.5\% dari tahun 2005 sampai 2015. (Benjamin EJ., et al 2018) Akan tetapi data prevalensi hipertensi di Indonesia belum tersedia. (Peltzer K., Pengpid S., 2018)

Salah satu penyebab terjadinya peningkatan prevalensi hipertensi pada kelompok muda adalah obesitas. Secara global, proporsi overweight dan obesitas pada orang dewasa meningkat dari tahun 1980 sampai 2013 yaitu sebesar $28.8 \%$ menjadi $36.9 \%$ pada pria dan $29.8 \%$ menjadi $38 \%$ pada wanita. Obesitas tidak hanya terjadi pada orang dewasa, melainkan juga terjadi pada anak-anak usia 2-5 tahun sebesar 9.4\% dan usia 6-11 tahun sebesar 17.4\%. (Benjamin EJ., et al 2018) Hubungan erat antara hipertensi, obesitas dan peningkatan prevalensi obesitas pada anakanak menandakan bahwa hipertensi dan prehipertensi menjadi masalah kesehatan yang signifikan pada kaum muda. (Kaiser P., 2013) 
Faktor yang dapat menyebabkan hipertensi dibagi menjadi dua kelompok yaitu faktor yang tidak dapat dimodifikasi seperti jenis kelamin, umur, genetik dan faktor yang dapat dimodifikasi seperti pola makan, kebiasaan berolahraga, dan kebiasaan merokok. (Fitriana R., 2012) Berdasarkan penelitian, kebiasaan mengonsumsi makanan yang mengandung tinggi energi, lemak jenuh, natrium, dan rendah serat dapat meningkatkan risiko hipertensi. (Kar S. \& Khandelwal B., 2015) Kandungan zat gizi tersebut terdapat dalam makanan cepat saji, sehingga konsumsi makanan cepat saji yang berlebih perlu diperhatikan. (Pendick D., 2013) (He FJ. \& MacGregor GA, 2006)

Definisi makanan cepat saji menurut KBBI adalah makanan yang pengolahannya dan penyajiannya dilakukan dengan serba cepat. (KBBI, 2016) Makanan cepat saji disebut juga sebagai makanan sampah (junk food) karena kadar gizinya yang rendah dan dampak negatif yang ditimbulkannya. Makanan cepat saji dibagi menjadi makanan cepat saji modern dan makanan cepat saji tradisional. Yang tergolong sebagai makanan cepat saji modern antara lain adalah ayam goreng, kentang goreng, hamburger, pizza, spageti, dan sosis dari berbagai merk dagang. Sedangkan yang tergolong sebagai makanan cepat saji tradisional adalah mie goreng, mie instan, bakso, mie ayam, gorengan, siomay, soto, dan pecel. (Nadya K., 2016) Namun pada penelitian ini hanya akan dibatasi pada makanan cepat saji modern seperti ayam goreng, kentang goreng, burger, pizza, spaghetti, sosis, dan donat

Secara umum penelitian ini bertujuan untuk mengetahui hubungan antara frekuensi konsumsi makanan cepat saji dengan tekanan darah pada remaja SMP Permai Penjaringan Jakarta Utara. Secara khusus penelitian ini bertujuan untuk mengetahui gambaran tekanan darah pada remaja SMP Permai Penjaringan Jakarta Utara yang mengonsumsi makanan cepat saji modern dan hubungan antara frekuensi konsumsi makanan cepat saji dengan tekanan darah pada remaja SMP Permai Penjaringan Jakarta Utara.

Penelitian ini memiliki beberapa keterbatasan seperti: jumlah variabel yang diteliti hanya satu variabel, sedangkan tekanan darah dipengaruhi oleh berbagai faktor, selain itu pengambilan data mengenai frekuensi konsumsi makanan cepat saji dengan kuesioner tidak memiliki keakuratan yang tinggi. Penelitian dilakukan dengan metode potong lintang sehingga hubungan kausalitas tidak dapat dinilai dengan akurat.

\section{METODE PENELITIAN}

\section{Alat dan Bahan}

Pengumpulan data pada penelitian ini menggunakan kuesioner Food Frequency Questionnaire, sphygmomanometer Riester® untuk mengukur tekanan darah, poster tinggi badan untuk mengukur tinggi badan, dan timbangan untuk mengukur berat badan.

\section{Jalannya Penelitian}

Penelitian ini menggunakan desain penelitian potong lintang untuk melihat hubungan frekuensi konsumsi makanan cepat saji dengan tekanan darah pada siswa dan siswi kelas IX SMP Permai Penjaringan Jakarta Utara yang berlokasi di Jalan Pluit Karang Barat Blok O-VI No.1. Pengumpulan data dilakukan selama satu bulan terhitung dari 29 Agustus 2017 sampai dengan 29 September 2017. Pengambilan sampel menggunakan metode purposif sebanyak 123 sampel, dengan kriteria inklusi seperti: siswa dan siswi SMP Permai Penjaringan Jakarta Utara yang berusia 14 - 16 tahun, gemar mengonsumsi makanan cepat saji modern, bersedia untuk mengisi kuesioner, dan bersedia untuk diukur tekanan darahnya menggunakan sphygmomanometer; 
sedangkan kriteria eksklusi seperti: siswa dan siswi SMP Permai Penjaringan Jakarta Utara yang menolak untuk ikut serta dalam penelitian, rutin mengonsumsi obat hipertensi, dan memiliki riwayat penyakit jantung.

Responden diminta untuk mengisi lembar persetujuan dan kuesioner frekuensi konsumsi makanan cepat saji yang memiliki pertanyaan seberapa seringnya responden mengonsumsi makanan cepat saji selama satu bulan terakhir, setelah itu dilakukan pengukuran tekanan darah, tinggi badan dan berat badan responden.

Frekuensi konsumsi makanan cepat saji dapat dikategorikan menjadi "Sering" apabila responden menginsumsi makanan cepat saji minimal 2 kali dalam seminggu, dan dikategorikan "Jarang" apabila menkonsumsi makanan cepat saji kurang dari 2 kali dalam seminggu. (Mihrete K., 2012) Pada anak-anak dan remaja usia 1 sampai 17 tahun, hipertensi diartikan sebagai tekanan darah sistolik dan atau diastolik lebih besar sama dengan persentil 95 untuk usia, jenis kelamin, dan tinggi badan (Anyaegbu E.I., \& Dharnidharka V.R., 2013).

Tabel I. Kriteria diagnosis hipertensi pada anak dan remaja (Anyaegbu E.I., \& Dharnidharka V.R., 2013)

\begin{tabular}{ll}
\hline & Persentil tekanan darah sistolik atau diastolik \\
\hline Normal & $<99^{\mathrm{th}}$ percentile \\
Prehipertensi & $90^{\mathrm{th}}$ percentile $-95^{\mathrm{th}}$ percentile \\
Hipertensi tingkat 1 & $95^{\mathrm{th}}$ percentile $-99^{\mathrm{th}}$ percentile $+5 \mathrm{mmHg}$ \\
Hipertensi tingkat 2 & $>99^{\mathrm{th}}$ percentile $+5 \mathrm{mmHg}$ \\
\hline
\end{tabular}

Keterangan :

"Meningkat" : bila tekanan sistolik dan atau tekanan diastolik lebih besar dari persentil ke 90 untuk usia, jenis kelamin, dan tinggi badan.

"Normal" : bila tekanan sistolik dan atau tekanan diastolik lebih kecil sama dengan persentil ke 90 untuk usia, jenis kelamin, dan tinggi badan.

\section{Analisis data}

Analisis data menggunakan uji univariat dan bivariat. Uji univariat digunakan untuk mendeskripsikan data dari sampel, sedangkan uji bivariat dilakukan untuk melihat apakah terdapat hubungan antara dua variabel. Uji normalitas distribusi data menggunakan uji Kolmogorov-Smirnov. Data yang memiliki distribusi normal, dilakukan pengukuran hubungan antar variabel dengan menggunakan uji kai kuadrat karena kedua variabel merupakan variabel kategorik. Data yang memiliki distribusi tidak, dilakukan uji alternatif Fisher Exact. Hubungan antara frekuensi konsumsi makanan cepat saji responden terhadap tekanan darah responden dianalisis menggunakan uji kai kuadrat dengan $\alpha=0,05$ dan taraf kemaknaan 95\%.

\section{HASIL DAN PEMBAHASAN}

Karakteristik responden berdasarkan jenis kelamin, frekuensi konsumsi makanan cepat saji, tekanan darah, dan indeks massa tubuh dapat dilihat pada Tabel I. Karakteristik responden pada penelitian ini meliputi 50 orang laki-laki dan 73 orang perempuan. Responden yang sering mengonsumsi makanan cepat saji sebanyak $67.5 \%$ sedangkan yang jarang mengonsumsi makanan cepat saji sebanyak 32.5\%. Responden dengan tekanan darah meningkat sebanyak 13\% sedangkan 
responden dengan tekanan darah normal sebesar 87\%. Responden dengan BMI obese sebanyak $13.8 \%$, overweight sebanyak $11.4 \%$, dan normal sebanyak $74.8 \%$.

Tabel II. Karakteristik Responden

\begin{tabular}{llc}
\hline & & $\mathbf{n}(\mathbf{\%})$ \\
\hline Jenis Kelamin & Laki-laki & $50(40.65 \%)$ \\
& Perempuan & $73(59.35 \%)$ \\
Frekuensi Konsumsi & Jarang & $40(32.5 \%)$ \\
Makanan Cepat Saji & Sering & $83(67.5 \%)$ \\
Tekanan Darah & Normal & $107(87 \%)$ \\
& Meningkat & $16(13 . \%)$ \\
BMI & Normal & \\
& Overweight & $92(74.8 \%)$ \\
& Obese & $14(11.4 \%)$ \\
& & $17(13.8 \%)$ \\
\hline
\end{tabular}

Data responden laki-laki dan perempuan dikelompokkan berdasarkan tekanan darah menjadi normal dan tidak normal pada Tabel II. Responden laki-laki dengan tekanan darah meningkat sebanyak 30\% sedangkan responden laki-laki dengan tekanan darah normal sebanyak 70\%. Responden perempuan dengan tekanan darah meningkat sebanyak $1.4 \%$ sedangkan responden perempuan dengan tekanan darah normal sebanyak $98.6 \%$

Tabel III. Tekanan Darah

\begin{tabular}{lll}
\hline & Tekanan Darah & \multicolumn{1}{c}{$\mathbf{n ( \% )}$} \\
\hline Laki-laki & Normal & $35(70 \%)$ \\
& Meningkat & $15(30 \%)$ \\
Perempuan & Normal & $72(98.6 \%)$ \\
& Meningkat & $1(1.4 \%)$ \\
\hline
\end{tabular}

Data responden laki-laki dan perempuan dikelompokkan berdasarkan frekuensi makan makanan cepat saji menjadi jarang dan sering pada Tabel III. responden laki-laki yang sering mengonsumsi makanan cepat saji sebanyak $80 \%$ sedangkan responden laki-laki yang jarang mengonsumsi makanan cepat saji sebanyak 20\%. Responden perempuan yang sering mengonsumsi makanan cepat saji sebanyak 58.9\% sedangkan responden perempuan yang jarang mengonsumsi makanan cepat saji sebanyak $41.1 \%$. 
Tabel IV. Frekuensi Konsumsi Makanan Cepat Saji

\begin{tabular}{lcc}
\hline & $\begin{array}{c}\text { Frekuensi Konsumsi } \\
\text { Makanan Cepat Saji }\end{array}$ & n (\%) \\
\hline Laki-laki & Jarang & $10(20 \%)$ \\
& Sering & $40(80 \%)$ \\
Perempuan & Jarang & $30(41.1 \%)$ \\
& Sering & $43(58.9 \%)$ \\
\hline
\end{tabular}

Data responden yang diperoleh diolah dengan menggunakan uji Kai Kuadrat. Pada Tabel IV. data tekanan darah menjadi normal dan tidak normal, untuk data frekuensi konsumsi makanan cepat saji dibagi menjadi sering dan jarang.

Tabel V. Hubungan Frekuensi Konsumsi Makanan Cepat Saji dengan Tekanan Darah

\begin{tabular}{|c|c|c|c|c|c|}
\hline & & & \multicolumn{2}{|c|}{ Tekanan Darah } & \multirow[t]{2}{*}{ Total } \\
\hline & & & Normal & Meningkat & \\
\hline $\begin{array}{l}\text { Frekuensi } \\
\text { Konsumsi }\end{array}$ & Jarang & Count & 35 & 5 & 40 \\
\hline $\begin{array}{l}\text { Makanan } \\
\text { Cepat Saji }\end{array}$ & Sering & Count & 72 & 11 & 83 \\
\hline Total & & Count & 107 & 16 & 123 \\
\hline
\end{tabular}

Pada penelitian ini, responden yang jarang mengonsumsi makanan cepat saji dengan tekanan darah normal sebanyak 35 orang. Responden yang jarang mengonsumsi makanan cepat saji dengan tekanan darah meningkat sebanyak 5 orang. Responden yang sering mengonsumsi makanan cepat saji dengan tekanan darah normal sebanyak 72 normal. Responden yang sering mengonsumsi makanan cepat saji dengan tekanan darah meningkat sebanyak 11 orang.

Setelah data responden dikelompokkan, dilakukan pengolahan data menggunakan uji Kai Kuadrat. Hasil dari uji Kai Kuadrat ditampilkan pada Tabel VI.

Tabel VI. Hasil Uji Kai Kuadrat

$\begin{array}{ccccc}\text { Value df } & \begin{array}{c}\text { Asymptotic } \\ \text { Significance } \\ \text { (2-sided) }\end{array} & \begin{array}{c}\text { Exact Sig. } \\ \text { (2-sided) }\end{array} & \begin{array}{c}\text { Exact Sig. } \\ \text { (1-sided) }\end{array} \\ \end{array}$

\begin{tabular}{lccccc}
\hline & 0,014 & 1 & 0,907 & & \\
Pearson Chi-Square & 0,000 & 1 & 1,000 & & \\
Continuity Correction & 0,014 & 1 & 0,907 & 1,000 & 0,577 \\
Likelihood Ratio & & & & & \\
Fisher's Exact Test & 0,013 & 1 & 0,908 & \\
Linear-by-Linear & & & & \\
Association & 123 & & & \\
\hline N of Valid Cases & & & & \\
\hline
\end{tabular}


Dalam penelitian ini mayoritas responden sering mengonsumsi makanan cepat saji $(67.5 \%)$. Hal ini sesuai dengan penelitian The National Restaurant Association yang menyatakan bahwa sebagian besar warga Amerika, terutama anak-anak dan remaja lebih sering mengonsumsi makanan cepat saji. Pola makan seperti ini dipengaruhi oleh gaya hidup dimana orang tua sibuk bekerja, sehingga makanan cepat saji menjadi pilihan utama karena membutuhkan waktu singkat, tempat nyaman, rasa yang enak, dan harga yang cukup bersaing (Luce DD. \& Motil KJ., 2018).

Berdasarkan data frekuensi konsumsi makanan cepat saji pada responden laki-laki dan perempuan didapatkan $80 \%$ laki-laki dan $58.9 \%$ perempuan yang sering mengonsumsi makanan cepat saji. Ini menunjukkan laki-laki lebih sering mengonsumsi makanan cepat saji dibandingkan dengan perempuan. Hal ini dikarenakan laki-laki memiliki tingkat asupan energi yang lebih tinggi dibandingkan perempuan (Morse KL. \& Driskell JA., 2009) dan menurut Le Blanc et al (2015), perempuan lebih mementingkan konten nutrisi dalam makanan yang dikonsumsi dibandingkan dengan laki-laki.

Data berdasarkan tekanan darah terdapat $30 \%$ laki-laki dan $1.4 \%$ perempuan yang mengalami peningkatan tekanan darah menurut tabel tekanan darah untuk usia, jenis kelamin, dan tinggi badan. Ini menunjukkan laki-laki memiliki rata-rata tekanan darah yang lebih tinggi dari perempuan. Hal ini dikarenakan laki-laki-laki memiliki tekanan darah yang lebih tinggi dibandingkan dengan perempuan pre-menopause yang mungkin dikarenakan peran hormon androgen (Maranon R. \& Reckelhoff JF., 2013). BMI juga dapat mempengaruhi tekanan darah. Berdasarkan penelitian LA de Hoog. et al (2012), terdapat hubungan antara BMI dengan tekanan darah pada anak-anak dari etnis yang berbeda, sebesar $70 \%$ laki-laki dan $98.6 \%$ perempuan memiliki tekanan darah yang normal menurut tabel tekanan darah untuk usia, jenis kelamin, dan tinggi badan. Hal ini mungkin dikarenakan kebanyakan $(90.2 \%)$ responden memiliki rutinitas aktivitas fisik (Hower IM. et al, 2018).

Dari tabel hubungan frekuensi konsumsi makanan cepat saji dengan tekanan darah, didapatkan bahwa kelompok yang jarang mengonsumsi makanan cepat saji lebih sedikit responden yang mengalami peningkatan tekanan darahnya dibandingkan dengan kelompok yang sering mengonsumsi makanan cepat saji. Ini dapat terjadi karena kebiasaan mengonsumsi makanan cepat saji yang dapat meningkatkan BMI sehingga meningkatkan tekanan darah dan kadar natrium dalam makanan cepat saji yang tinggi yang menyebabkan retensi cairan tubuh. Retensi cairan tubuh ini akan menyebabkan peningkatan venous return. Peningkatan venous return menyebabkan peningkatan kontraktilitas jantung berdasarkan hukum Frank-Starling, meningkatkan stroke volume jantung dan meningkatkan cardiac output, yang mengakibatkan peningkatan tekanan darah rata-rata (Sherwood L., 2016).

Hasil dari pengolahan data didapatkan $\mathrm{p}$ sebesar $0,907(\mathrm{p}>0.05)$ sehingga dapat disimpulkan bahwa tidak terdapat hubungan yang bermakna antara frekuensi konsumsi makanan cepat saji dengan tekanan darah pada remaja SMP Permai Penjaringan Jakarta Utara. Hasil ini sesuai dengan penelitian oleh Syafni A. yang tidak menemukan hubungan bermakna antara konsumsi western fast food dengan hipertensi pada remaja di SMA N 1 Semarang (Syafni A. \& Wijayanti HS., 2015). Penelitian oleh Tri FF menemukan hubungan antara indeks massa tubuh dan aktivitas fisik terhadap tekanan darah namun tidak terdapat hubungan bermakna antara konsumsi western fast food dengan tekanan darah (Hower IM. et al, 2018).

Saat pengisian kuesioner frekuensi konsumsi makanan cepat saji ditanyakan mengenai data frekuensi konsumsi selama 1 bulan terakhir dan responden mengisi kuesioner sesuai dengan 
ingatan mereka selama 1 bulan terakhir tersebut, sehingga dapat timbul Recall bias. Saat pengukuran tekanan darah menggunakan sphigmomanometer, tekanan darah beberapa responden ditemukan sangat tinggi karena efek "white coat" yang menyebabkan laju jantung responden meningkat saat pemeriksaan karena anxietas responden (Kasper D. et al, 2015). Waktu dilakukannya pemeriksaan tekanan darah juga dapat mempengaruhi hasil dari pemeriksaan, dimana tekanan darah paling tinggi didapatkan di pagi hari dibandingkan dengan waktu lain di hari yang sama. ${ }^{12}$ Saat dilakukan pemeriksaan tekanan darah juga tidak diketahui apakah responden baru saja melakukan aktivitas fisik yang dapat mempengaruhi hasil karena peningkatan laju dan kontraktilitas jantung (Sherwood L., 2016).

\section{KESIMPULAN}

Tidak terdapat hubungan antara frekuensi konsumsi makanan cepat saji dengan tekanan darah pada remaja SMP Permai Penjaringan Jakarta Utara. Hal ini dapat disebabkan oleh berbagai faktor yang mempengaruhi tekanan darah seperti faktor genetik, ciri perseorangan, gaya hidup, konsumsi obat-obatan, alkohol, stress, dan lain-lain. Untuk penelitian selanjutnya, diharapkan dapat meneliti lebih lanjut faktor-faktor lain yang dapat mempengaruhi tekanan darah pada remaja dan dapat dilakukan penelitian dengan rancangan penelitian yang lain seperti eksperimental atau case control.

\section{DAFTAR PUSTAKA}

Anyaegbu, E. I., \& Dharnidharka, V. R. 2013. Hypertension in the teenager. Pediatric clinics of North America, 61(1), 131-51.

Benjamin, E.J. Virani, S.S. Callaway, C.W. Chamberlain, A.M. Chang, A.R. Cheng, S. et al 2018. Heart Disease and Stroke Statistic 2018, Circulation 137(12): e67-e492.

Fitriana, R. Lipoeto, N.I. Triana, V. 2012. Faktor risiko kejadian hipertensi pada remaja di wilayah kerja puskesmas rawat inap sidomulyo kota Pekanbaru. J Kesehatan Masyarakat Andalas 7(1):10-5.

He, F.J., MacGregor, G.A.. 2006. Importance of salt in determining blood pressure in children meta-analysis of controlled trials. Hypertension 48(5): 861-9.

Hower, I.M., Harper, S.A. and Buford, T.W. 2018. Circadian rhythms, exercise, and cardiovascular health. Journal of Circadian Rhythms 16(1): 7.

Hussain, M.A., Mamun, A.A., Reid, C. \& Huxley, R.R.. 2016. Prevalence, awareness, treatment and control of hypertension in indonesian adults aged $\geq 40$ years: findings from the indonesia family life survey (IFLS). PLoS ONE 11(8).

Kaiser, P. 2013. Overweight, obese children face high risk of hypertension. ScienceDaily. Available from: www.sciencedaily.com/releases/2013/10/131010124606.htm. 
Kar, S. \& Khandelwal, B. 2015. Fast foods and physical inactivity are risk factors for obesity and hypertension among adolescent school children in east district of sikkim, India. Journal of natural science, biology, and medicine 6(2): 356-9.

Kasper,D., Fauci, A., Hauser, S., Longo, D., Jameson, J.L., Loscalzo, J. 2015. Harrison's Principles of Internal Medicine. $19^{\text {th }}$ Ed. McGraw Hill Education. USA.

KBBI Online. 2017. Makanan cepat saji. Diunduh dari: https://kbbi.kata.web.id/makan-cepat-saji/ diakses: 24 Februari 2017.

LA de Hoog, M., van Eijsden, M., Stronks, K., Gemke, R.J., Vrijkotte, T.G. 2012. Association between body size and blood pressure in children from different ethnic origins. Cardiovasc Diabetol Lond 11: 136.

Leblanc, V., Bégin, C., Corneau, L., Dodin, S., Lemieux, S. 2015. Gender differences in dietary intakes: what is the contribution of motivational variables?. J Hum Nutr Diet Off J Br Diet Assoc 28(1): 37-46.

Luce, D.D. \& Motil, K.J. 2018. Fast food for children and adolescents. UpToDate, Available from: https://www.uptodate.com/contents/fast-food-for-children-and-adolescents\#H1.

Maranon, R., Reckelhoff, J.F. 2013. Sex and gender differences in control of blood pressure. Clinical Science 125: 311-8.

Mihrete, K. 2012. Association between fast food consumption and obesity and high blood pressure among office workers. Dissertation. Doctor of Public Health. Walden Univ. Minnesota.

Morse, K.L., Driskell, J.A. 2009. Observed sex differences in fast-food consumption and nutrition self-assessments and beliefs of college students. Nutr Res N Y N 29(3): 173-9.

Nadya, K. 2016. Hubungan konsumsi fast food dan soft drink terhadapsiswa obesitas dan tidak obesitas di SMAN 4 Medan. Medan. Diunduh dari: http://repository.usu.ac.id/handle/123456789/56210, diakses 24 Februari 2017.

Peltzer, K. \& Pengpid, S. 2018. The prevalence and social determinants of hypertension among adults in Indonesia: a cross-sectional population-based national survey. International Journal of Hypertension. Diunduh dari: https://doi.org/10.1155/2018/5610725.

Pendick, D. 2013. Sodium still high in fast food and processed foods, harvard health publishing. Available from: https://www.health.harvard.edu/blog/sodium-still-high-in-fast-food-andprocessed-foods-201305166267.

Sherwood, L. 2016. Human physiology from cells to systems. $9^{\text {th }}$ Ed. Brooks/Cole. USA.

Syafni, A. \& Wijayanti, H.S. 2015. Hubungan konsumsi western fast food dengan hipertensi pada remaja di SMA N 1 Semarang. J Nutr Coll 4(4): 358-64. 